\title{
Glyphosate in the production and forage quality of marandu grass
}

\section{Glifosato na produção e qualidade de forragem de capim marandu}

\author{
Luciane da Cunha Codognoto ${ }^{1 *}$; Thassiane Telles Conde ${ }^{2}$; Katia Luciene Maltoni3; \\ Glaucia Amorim Faria ${ }^{4}$
}

\section{Highlights}

An underdose of glyphosate alters specific biological characteristics in plants.

Glyphosate underdose increases biomass and crude protein production of marandu grass.

Food quality and functional variables were optimized by glyphosate underdose.

\begin{abstract}
The drift of the herbicide glyphosate, used for desiccating crops or controlling weeds, can result in growthpromoting or non-target plant development effects. Thus, it is possible to use the compound to increase the biomass of forage through the hormone effect. The objective of this study was to evaluate the effects of sublethal doses of glyphosate on the production of Urochloa brizantha cv. Marandu (Marandu grass) and its nutritional quality in ruminants. The design used was completely randomized, with five replications in a factorial scheme. The treatments used were as follows: control (without glyphosate application) and four sublethal doses of glyphosate $\left(4,10,14\right.$, and $20 \mathrm{~g} \mathrm{ha}^{-1}$ of the acid equivalent). The monthly collections consisted of collecting the plant material $(0.20 \mathrm{~m})$ from the surface, comprising of leaves and pseudocolmos (stem and leaf sheath) to determine the dry matter production and forage chemical-bromatological parameters. The results showed that leaf/stem ratio, neutral detergent fiber, and acid detergent fiber were affected exclusively by the harvest factor. The hormone effect of the herbicide occurs in the production of dry matter and lignin in the evaluated subdoses. For crude protein, there was an interaction between the factor doses and harvest, due to the effect of glyphosate and the management applied to the harvests, showing that the sublethal doses of glyphosate promoted the production of dry matter and the food quality of Marandu grass.
\end{abstract}

Key words: Harvest. Herbicid. Underdoses. Urochloa brizantha.

1 Agronomic Engineer, Federal Institute of Rondônia, IFRO, Ariquemes, RO, Brasil. E-mail: luciane.codognoto@ifro. edu.br

2 Profa Dra, Department of Education, IFRO/DE, Ariquemes, RO, Brasil. E-mail: thassiane.conde@ifro.edu.br

3 Profa Dra, Phytosanitary, Rural and Soil Engineering Department, Paulista State University "Júlio de Mesquita Filho", UNESP/DEFERS, Ilha Solteira, SP, Brasil. E-mail: katia.maltoni@unesp.br

4 Profa Dra, Mathematics Department, Paulista State University "Júlio de Mesquita Filho", UNESP/DMAT, Ilha Solteira, SP, Brasil. E-mail: glaucia.a.faria@unesp.br

* Author for correspondence

Received: Apr. 17, 2020 - Approved: Mar. 09, 2021 


\section{Resumo}

A deriva do herbicida glifosato, usado para dessecação de culturas ou no controle de plantas daninhas, pode resultar em efeitos promotores de crescimento ou desenvolvimento de plantas não alvo. Assim, surge a possibilidade de utilização do composto para incremento da biomassa de forrageiras, por efeito hormese. O objetivo deste trabalho foi avaliar os efeitos da aplicação de doses subletais de glifosato na produção de Urochloa brizantha cv. Marandu (capim Marandu) e sobre a qualidade nutricional para ruminantes. $O$ delineamento utilizado foi o inteiramente casualizado com cinco repetições, em esquema fatorial. Os tratamentos utilizados foram: controle (sem aplicação de glifosato) e quatro doses subletais de glifosato (4, 10, 14 e $20 \mathrm{~g} \mathrm{ha}^{-1}$ do equivalente ácido). As coletas mensais consistiram do recolhimento do material vegetal a 0,20 m da superfície, compreendendo folhas e pseudocolmos (colmo e bainha foliar) para determinação da produção de matéria seca e de parâmetros químico-bromatológicos da forragem. Os resultados mostraram que relação folha/colmo, fibra em detergente neutro e fibra em detergente ácido sofreram efeitos exclusivamente do fator corte. O efeito hormese do herbicida ocorre na produção de matéria seca e lignina nas subdoses avaliadas. Para proteína bruta houve interação entre os fatores doses e cortes, por efeito do glifosato e do manejo aplicado nos cortes, mostrando que as doses subletais do glifosato promovem a produção de matéria seca e a qualidade alimentar do capim Marandu.

Palavras-chave: Colheita. Herbicida. Subdoses. Urochloa brizantha.

\section{Introduction}

In agriculture, herbicides administered for the chemical control of weed plants in crops of commercial interest are essential for production. As a consequence, the hormone phenomenon can occur, which consists of a stimulatory or toxic biological response in plants, depending on the administration of a minimum or abundant dose of a certain compound (Gomes et al., 2017).

Glyphosate is the most widely used herbicides worldwide; it has systemic and non-selective action, capable of withering a wide variety of plant species (Brito, Tropaldi, Carbonari, \& Velini, 2017). The universal symptoms to the application of the herbicide are leaf chlorosis, followed by necrosis, characterizing the effect of photosynthesis, especially the route of shikimic acid and physiological processes. However, there are records of plants exposed to drift levels with a hormone effect on plant height, leaf area, aerial part mass, seed yield, and total biomass (Kappes, Arf, Arf, Gitti, \& Ferreira, 2012; Carbonari et al., 2014; Nascentes et al., 2017).

Brazil has the largest commercial bovine herd, and in addition, is the largest exporter and producer of meat annually, estimated at 10.3 million tons (United States Department of Agriculture [USDA], 2020). The cultivation of pastures for animal feed is fundamental to the success of Brazilian livestock, in economic terms, due to the low cost of production, based on the exploitation of the natural fertility of the soils or its correction. In this case, Urochloa brizantha cv. Marandu, introduced in 1984, is predominant in extensive livestock production systems, especially because of its adaptation to natural soils that have low to medium fertility.

Studies of the effects of hormones in Brachiaria grass on productive parameters and food quality have shown promising 
results. However, these results are restricted to immediate or unique evaluation, since the effectiveness or longevity of the herbicidal effect on plants is limited (Brito et al., 2017). Thus, the objective of this study was to evaluate the occurrence of hormones, through consecutive applications of very low doses of glyphosate, on the production and chemicalbromatological composition of $U$. brizantha $\mathrm{cv}$. Marandu.

\section{Material and Methods}

The experiment was installed in a greenhouse at the Federal Institute of Education, Science, and Technology of Rondônia (IFRO), Campus Ariquemes, from September 2018 to April 2019. The experimental design was completely randomized (CRD), in a factorial scheme, with plots subdivided over time and five repetitions, totaling 100 experimental units. The main factors were organized into five levels (D): control and four sublethal doses of glyphosate. The subsets of the experiment were the harvest $(H)$, which constituted the data collection, on four successive occasions. Only the root dry mass variable was analyzed in CRD, as there were no repetitions over time.

Urochloa Brizantha cv. Marandu (Marandu grass) seeds were obtained from a commercial lot sample $(2017 / 2018)$ with a cultural value of $55 \%$. The seedlings were contained in a styrofoam tray with 200 cells (one seedling per cell, conical in shape and with a volume of $15.6 \mathrm{~mL}$ ) until the $21^{\text {st }}$ day after sowing (DAS) and, on 06/10/2018, the transplant to pots was performed. Each pot $\left(7 \mathrm{dm}^{3}\right)$ represented an experimental unit and received three seedlings in an area of $0.0314 \mathrm{~m}^{2}$.
The substrate used, both for sowing and for conducting the experiment, consisted of homogenization of gully soil, washed sand, and organic compost in the following proportions: 60,26 , and $14 \%$, respectively. Fertility and substrate texture analyses were performed and the results showed: $\mathrm{pH}$, in water $=6.75$; organic

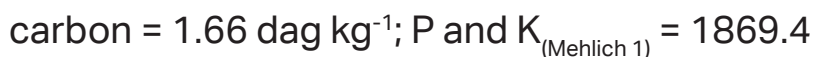
and $111 \mathrm{mg} \mathrm{dm}^{-3}$, respectively; $\mathrm{Ca}^{2+}, \mathrm{Mg}^{2+}$, and $\mathrm{Al}^{3+}{ }_{\left(\mathrm{KCl} 1 \mathrm{~mol}^{-1}\right)} \mathrm{L}^{-1}=5.83,2.08$, and $0.0 \mathrm{cmol}_{\mathrm{c}} \mathrm{dm}^{-3}$, respectively; base saturation $=88.7 \%$; and, clayey texture $\left(520,40\right.$, and $440 \mathrm{~g} \mathrm{~kg}^{-1}$ clay, silt, and sand, respectively). The substrate in the pots was accommodated considering an average density of $1.1 \mathrm{~kg} \mathrm{~m}^{-3}$ and maintaining humidity at roughly $60 \%$ of the field capacity.

After 52 DAS, on, 11/06/2018, a uniform cut of forage was carried out in all experimental plots, from the stratum above $0.20 \mathrm{~m}$ from the surface level (Dias, 2012), beginning the trial period. Nitrogen (urea) and potassium (potassium chloride) fertilization was carried out at three different times (12/06/2018, 01/05/2019, and 04/04/2019), totaling $50 \mathrm{~kg}$ ha $^{-1} \mathrm{~N}$ and $40 \mathrm{~kg} \mathrm{ha}^{-1} \mathrm{~K}_{2} \mathrm{O}$ (Cantarutti; Alvarez; \& Ribeiro, 1999).

On the seventh day after each harvest, treatments/levels (D) were applied: control and sublethal doses of glyphosate, equivalent to 4, 10,14 , and $20 \mathrm{~g} \mathrm{ha}^{-1}$ of the acid equivalent (a.e.). The commercial product Shadow (356 g a.e. $\mathrm{L}^{-1}$ ) was applied with a compression sprayer, pressure of 2 bar, with a bar adapted with a spray tip (DG11002 VS), providing a spray volume of $100 \mathrm{~L} \mathrm{ha}^{-1}$. Said products recommend a grace period of/reentry into pastures after two days.

The harvests of the experimental units occurred on the $21^{\text {st }}$ day after application of the sublethal doses of glyphosate: $1^{\text {st }}$ harvest (84 DAS), $2^{\text {nd }}$ harvest (112 DAS), $3^{\text {rd }}$ harvest 
(142 DAS), and $4^{\text {th }}$ harvest (172 DAS). Aerial plant production was measured as the total weight of green forage harvested in pots, 0.20 $\mathrm{m}$ from the surface. In addition, the material was separated into leaf blades and pride stock (stem + sheath).

Fresh mass of leaves and pride stock, and volume of roots harvested at the end of the experimental period were weighed and dried in a forced ventilation oven at $65^{\circ} \mathrm{C}$ until a constant mass was obtained. The dry mass of forage and roots, per pot, was determined in an oven at $105^{\circ} \mathrm{C}$ for $24 \mathrm{~h}$.

Forage fractions were crushed in a Willey knife mill with $1 \mathrm{~mm}$ mesh for the determination of crude protein (CP) by the Kjeldahl method; neutral and acid detergent fibers (NDF and ADF) by the Ankom $^{\circledR}$ Filter Bag Technique method; and lignin (LIG) was oxidized to potassium permanganate (Detmann et al., 2012).
With the aid of SISVAR software(Ferreira, 2019), the data were subjected to analysis of variance by the $\mathrm{F}$ test, and when significant, the effect of sublethal doses of glyphosate (D) and the interaction between factors were evaluated by regression, and the effects of the harvest (H) was compared with the Scott-Knott means test, at the level of $5 \%$ significance.

\section{Results and Discussion}

The analysis of variance indicated the significance of the underdoses of glyphosate for dry matter (DM) and LIG production in Marandu grass. The periodic harvest significantly influenced $D M$, leaf/ stem ratio (L/S), NDF, ADF, and LIG. The interactions showed significant effects on the CP content, which was an indication of the interdependence of factors $\mathrm{D}$ and $\mathrm{H}$ (Table 1).

\section{Table 1}

Analysis of variance of dry mass production (DM), leaf/stem ratio (L/S), crude protein (CP), neutral detergent fiber (NDF), acid detergent fiber (ADF), and grass lignin (LIG) in Marandu grass due to underdoses of glyphosate (D), and harvest $(\mathrm{H})$

\begin{tabular}{|c|c|c|c|c|c|}
\hline Variables & Dose (D) & Harvest (H) & $\mathrm{D} \times \mathrm{H}$ & $\mathrm{CV}^{(1)}$ & Mean \\
\hline & ----------- & -- Valor of $\mathrm{F}$ - & ----------- & -- (\%) -- & ---------- \\
\hline DM (g vase ( $\left.^{-1}\right)$ & $9,537^{* *}$ & $1112,469^{* *}$ & $0,376^{\text {ns }}$ & 7,09 & 9,59 \\
\hline L/S & $1,414^{\mathrm{ns}}$ & $20,387^{* *}$ & $1,284^{\mathrm{ns}}$ & 37,91 & 4,24 \\
\hline CP (\% DM) & $16,822^{* *}$ & $10,797^{* *}$ & $17,709 * *$ & 7,43 & 12,05 \\
\hline NDF (\% DM) & $1,702^{\text {ns }}$ & $5,190^{*}$ & $1,823^{\mathrm{ns}}$ & 5,24 & 63,01 \\
\hline ADF (\% DM) & $1,701^{\mathrm{ns}}$ & $8,436^{* *}$ & $1,663^{\text {ns }}$ & 8,39 & 30,88 \\
\hline LIG (\% DM) & 31,279 ** & $8,123^{* *}$ & $1,447^{\text {ns }}$ & 26,96 & 2,44 \\
\hline
\end{tabular}

(1) Coefficient of variation. **, ${ }^{*}$ and ns, significant to $1 \%, 5 \%$ and non-significant, respectively, by the Test $F$.

The split of glyphosate and the witnessed subdose between the harvests characterized the superiority of the $1^{\text {st }}$ harvest at doses of 10,14 , and $20 \mathrm{~g}$ a.e. $\mathrm{ha}^{-1}$ of the compound (Table 2). CP includes substances with chemical similarities, such as nucleic acids, amines, carbohydrates, and lipids replaced by nitrogenous radicals and non- 
protein amino acids (Detmann et al., 2012). The average CP content recorded (Table 1) describes the enrichment of free amino acids, suggesting that proteolytic activities are influenced by herbicide treatment, implying a hormone effect.

Glyphosate underdoses showed different effects on CP production (Figure 1). There was an increasing linear performance for the $1^{\text {st }}$ and $2^{\text {nd }}$ harvest with maximum CP content at the subdose of glyphosate acid equivalent (a.e.), $20 \mathrm{~g} \mathrm{ha}^{-1}$, obtaining an increase in relation to the control equivalent to 81,52 and $45.56 \%$, respectively, indicating the hormone effect. However, for the $3^{\text {rd }}$ harvest, the behavior was adjusted to the quadratic model and decreased from the estimated doses of 10.24 and $10.82 \mathrm{~g}$ a.e. ha-1 of glyphosate. At this level, the increase in CP on the control corresponds to 4.60 and $11.32 \%$, respectively. From then on, there was a depressive effect on CP production.
When assessing disturbances in the metabolism of amino acids associated with inhibition of photosynthesis in glyphosateresistant and susceptible soybean genotypes, Vivancos et al. (2011) found that nitrogenrich amino acids were triggered by changes in proteins involved in photosynthesis and photorespiration. Thus, the nutritive value of forage, especially $\mathrm{CP}$, can be altered by the rational and controlled use of sublethal doses of glyphosate.

The LIG values showed significant reductions, characterizing linear behavior inversely proportional to glyphosate doses (Figure 2B). The limit dose (20 g a.e. ha ${ }^{-1}$ of glyphosate) resulted in a reduction equivalent to $49.85 \%$ of the LIG content in relation to the control treatment. Zobiole, Bonini, Oliveira, Kremer and Ferrarese (2010) observed that with an increase in glyphosate doses, there was damage to the LIG content in herbicideresistant soy.

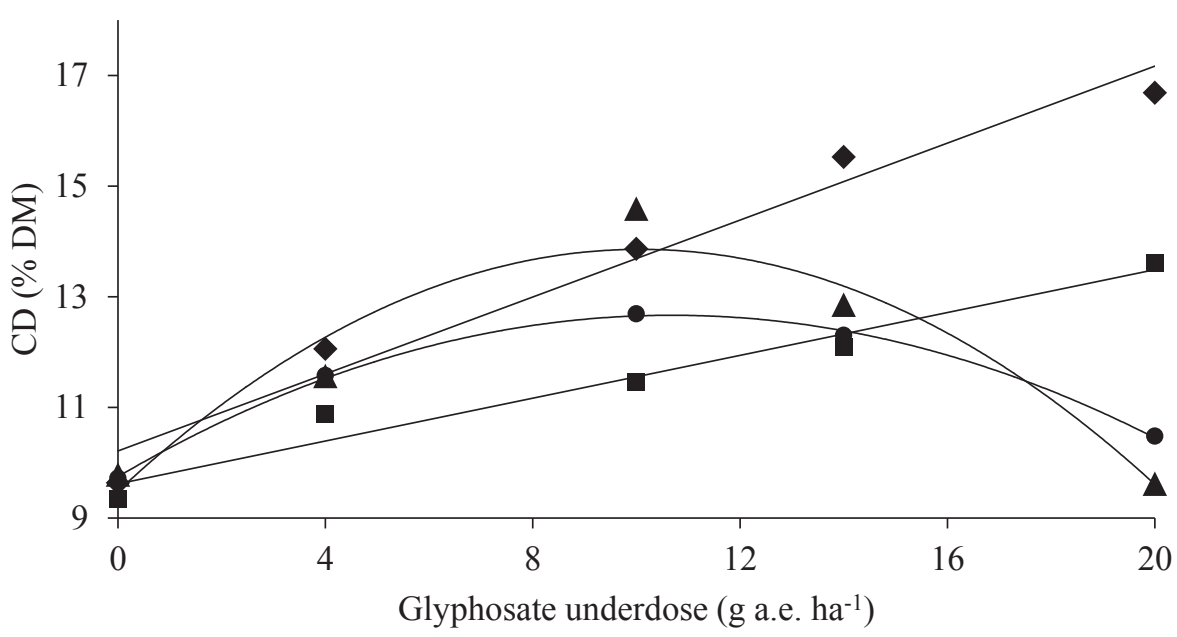

$\begin{array}{ll}1^{\text {st }} \text { harvest } & (\bullet): \hat{y}=+0,3695 x+9,9773 ; R^{2}=0,9877 \\ 2^{\text {nd }} \text { harvest } & (\square): \hat{y}=+0,1834 x+9,6420 ; R^{2}=0,9323 \\ 3^{\text {rd }} \text { harvest } & (\Delta): \hat{y}=-0,0460 x^{2}+0,9413 x+9,3651 ; R^{2}=0,9376 \\ 4^{\text {th }} \text { harvest } & (\bullet): \hat{y}=-0,0268 x^{2}+0,5799 x+9.6904 ; R^{2}=0,9902\end{array}$

Figure 1. Crude protein (CP) in Marandu grass exposed to underdoses of glyphosate, in four evaluation harvests. 
Table 2

Crude protein from Marandu grass submitted to underdoses of glyphosate and control, according to evaluation harvest

\begin{tabular}{cccccc}
\hline & \multicolumn{5}{c|}{ Glyphosate underdoses $\left(\mathrm{g}\right.$ a.e. ha $\left.\mathrm{A}^{-1}\right)$} \\
\cline { 2 - 6 } Harvest & 0 & 4 & 10 & 14 & 20 \\
\hline $1^{\text {st }}$ & $9,63 \mathrm{a}^{(1)}$ & $11,86 \mathrm{a}$ & $13,86 \mathrm{a}$ & $15,52 \mathrm{a}$ & $17,48 \mathrm{a}$ \\
$2^{\text {nd }}$ & $9,35 \mathrm{a}$ & $10,87 \mathrm{a}$ & $11,46 \mathrm{c}$ & $12,09 \mathrm{~b}$ & $13,61 \mathrm{~b}$ \\
$3^{\text {rd }}$ & $9,79 \mathrm{a}$ & $11,57 \mathrm{a}$ & $14,59 \mathrm{a}$ & $12,85 \mathrm{~b}$ & $9,62 \mathrm{c}$ \\
$4^{\text {th }}$ & $9,72 \mathrm{a}$ & $11,58 \mathrm{a}$ & $12,69 \mathrm{~b}$ & $12,30 \mathrm{~b}$ & $10,48 \mathrm{c}$ \\
\hline
\end{tabular}

(1) Averages followed by the same letter in the column do not differ statistically $(p>0.05)$ by the Scott-Knott test.

There was a potential indication for the use of management to improve productivity, since the treatment (sublethal dose of glyphosate) had a stimulating effect on the DM of the forage, as evidenced by positive and linear behavior, according to the adjusted mathematical model (Figure 2A). The $20 \mathrm{~g}$ a.e. ha $^{-1}$ dose of glyphosate provided an increase in DM equivalent to $9.20 \%$, compared to the control treatment. Among the evaluative harvests, the DM obtained in the $1^{\text {st }}$ harvest differed significantly from the subsequent cuts, with lower production masses (Table 2). Therefore, for hormone evaluation, consecutive applications characterize the depressive effect on forage yield.
LIG is a highly complex phenolic molecule, and in the feeding of ruminants, it interferes with nutritional quality, as it compromises the digestibility of forage nutrients and, consequently, animal productivity in pastures (Berchielli, Pires, \& Oliveira, 2011). The LIG content obtained for the studied doses, including the control treatment, was lower than that obtained by Meschede, Velini, Carbonari and Moraes (2011) when evaluating the effect of glyphosate in Urochloa decumbens pasture, established 8 years ago, registering 24.54 , and $26.11 \%$, at 30 and 60 days after application, respectively. However, the authors found a depressive effect (about $40 \%$ ) in the levels of LIG at higher doses (36, 72,180 , and $360 \mathrm{~g}$ a.e. ha-1 of glyphosate) in relation to the control. 
(A)

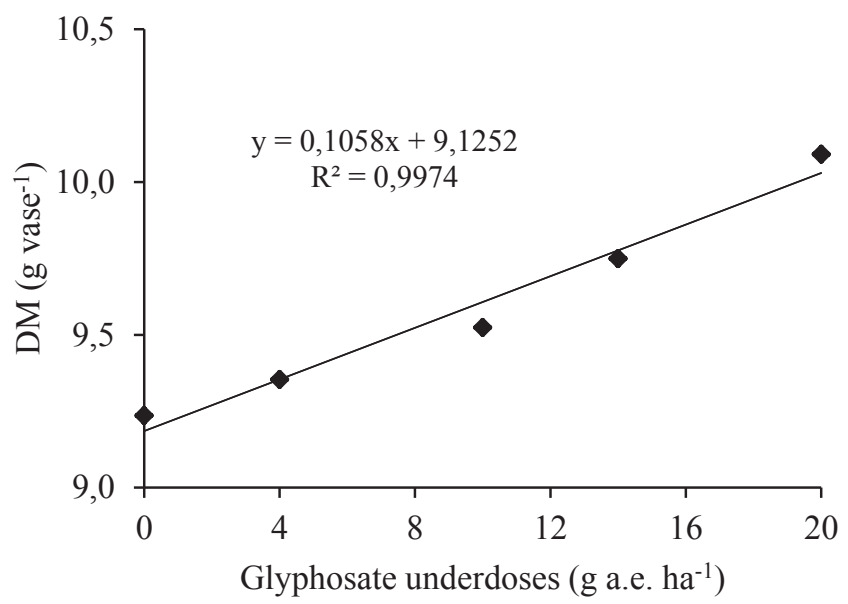

(B)

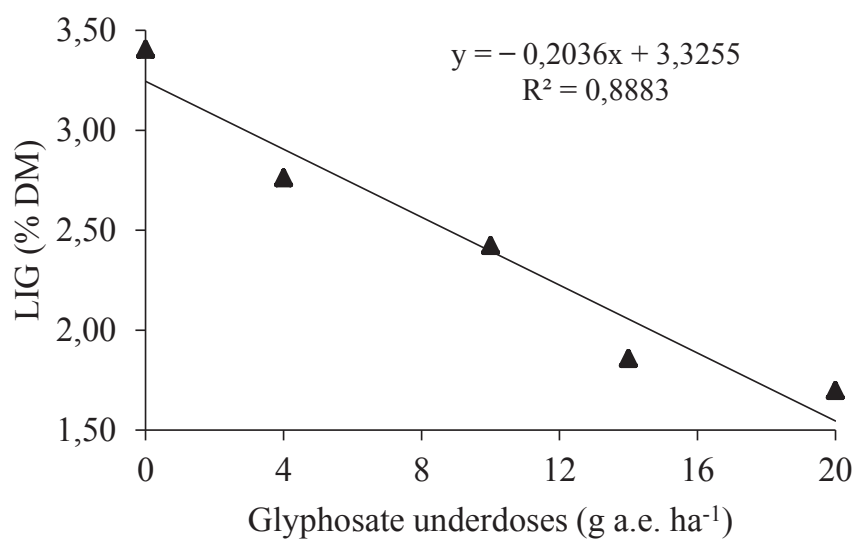

Figure 2. Production of dry matter (A) and lignin (B) of Marandu grass as a function of exposure to glyphosate underdoses.

Glyphosate has been proposed as a growth regulator in some crops, such as Crotalaria and upland rice, or to eliminate the lodging of rice plants (Gitti et al., 2011; Kappes et al., 2012). However, this practice resulted in reduced production. In addition to the functions inherent to plant physiology, lignification is an adaptive mechanism for stability and tolerance to abiotic and biotic stresses (Taiz \& Zeiger, 2013). The literature reports that there is a threshold between the concentrations of the herbicide used for this purpose, where higher doses of glyphosate do not alter the levels of LIG, since there is herbicidal action and this does not regulate growth or LIG content (Meschede et al., 2011).

In the temporal evaluation, the $1^{\text {st }}$ harvest presented a significantly higher LIG content than the other evaluations (Table 3). Successive applications have characterized the behavior of plant growth regulation, since the inhibition of the enzyme 5-enolpyruvylchiquimate-3-phosphate synthase (EPSPS) affects the production of LIG, interfering with carbon metabolism, depressing lignification, and prioritizing nonstructural carbohydrate metabolism. 
Table 3

Production of dry matter (DM), neutral detergent fiber (NDF), acid detergent fiber (ADF), lignin (LIG), and leaf/stem ratio (L/S) of Marandu grass in four evaluative harvest

\begin{tabular}{cccccc}
\hline Harvest & DM & LIG & NDF & ADF & L/S \\
\hline & $--\left(\right.$ g vase $\left.^{-1}\right)--$ & ------------ & $(\%$ DM) \\
$1^{\text {st }}$ & $16,17 \mathrm{a}^{(1)}$ & $2,98 \mathrm{a}$ & $63,68 \mathrm{a}$ & $31,60 \mathrm{a}$ & $2,71 \mathrm{c}$ \\
$2^{\text {nd }}$ & $7,77 \mathrm{c}$ & $2,15 \mathrm{~b}$ & $61,29 \mathrm{~b}$ & $29,50 \mathrm{~b}$ & $3,87 \mathrm{~b}$ \\
$3^{\text {rd }}$ & $5,86 \mathrm{~d}$ & $2,37 \mathrm{~b}$ & $62,38 \mathrm{~b}$ & $30,08 \mathrm{~b}$ & $4,56 \mathrm{a}$ \\
$4^{\text {th }}$ & $8,50 \mathrm{~b}$ & $2,23 \mathrm{~b}$ & $64,77 \mathrm{a}$ & $32,88 \mathrm{a}$ & $5,09 \mathrm{a}$
\end{tabular}

(1) Averages followed by the same letter in the column do not differ statistically $(p>0.05)$ according to the Scott-Knott test.

According to Gitti et al. (2011), carbon not assimilated in the lignification process, may have been responsible for the increase in $D M$, as shown in Figures $2 \mathrm{~A}$ and $2 \mathrm{~B}$. The production of LIG is controlled by phenylalanine, a key product of the chiquimate pathway (Zobiole et al., 2010) and, therefore, highly affected by glyphosate (Silva, Duke, Dayan, \& Velini, 2015). The reduction in the LIG content is an important physiological aspect, since this biopolymer integrates the indigestible fraction of the plants used in the feeding of ruminants, characterizing a gain in food quality (Berchielli et al., 2011).

Therewas an effect of factor $\mathrm{H}$, revealing a difference in the levels of NDF and ADF in the $1^{\text {st }}$ and $4^{\text {th }}$ harvest over the intermediate (Table 3). The levels of NDF obtained did not limit the consumption of forage. The limit of $65 \%$ NDF in DM in tropical forages, with a defoliation interval of 30 days, characterizes good nutritional value of forage, favoring animal performance and productivity in pastures (Alencar et al., 2010; Hanisch, Balbinot, \& Vogt, 2017).

The AFD levels obtained in this study (Table 3 ) positively relate to the digestibility of forage, indicating low levels of lignified components, favoring digestibility and the use of ingested forage (Oliveira, Bonfim-Silva, Silveira, \& Monteiro, 2010). AFD in forages with values of approximately $30 \%$ are considered ideal for animal consumption (Miranda et al., 2018). Meschede et al. (2011) tested the effect of glyphosate on chemical-bromatological variables of $U$. decumbens, with the initial dose of glyphosate being $32 \mathrm{~g}$ a.e. ha-1 and a control treatment (without application), obtaining AFD equivalent to 40.50 and $42.50 \%$, respectively, and they did not register a hormone effect.

The L/S ratio was not affected by glyphosate doses (Table 1). However, there was an effect of factor $\mathrm{H}$. Apical dominance was not influenced by chemical action, but by the management used. The growth of the grass, especially the L/S ratio, in response to defoliation, is due to the remaining height of the canopy $(0.20 \mathrm{~m})$, which positively influences the root reserves, and the maintenance of fertilizer and substrate moisture, which directly interferes with the production and quality of forage by stimulating the growth of tissues with high levels of $\mathrm{CP}$, along with low levels of NDF and LIG (Lopes, Cândido, Pompeu, Silva, \& Bezerra, 2011; Fontes et al., 2014). 
Furthermore, mineral nutrition can lead to resistance to glyphosate, as plants that have high concentrations of some cationic nutrients can significantly reduce the phytotoxic effects of the substance through the formation of poorly soluble complexes (Su, Ozturk, Cakmak, \& Budak, 2009). However, low doses of glyphosate alter the responses of plants to subsequent treatments with the herbicide (Silva et al., 2015). Thus, based on the data obtained for L/S ratio in the evaluated harvests (Table 2), it was found that the evaluated management is important for the productive, structural, and morphogenic characteristics of the forage canopy.

The underdoses of glyphosate had an effect on the dry mass of Marandu grass root (Table 4), and the subdose of $4 \mathrm{~g}$ a.e. ha $^{-1}$ had a hormonal effect (Figure 3 ). In foliar applications, the herbicide is quickly absorbed and transported to plant tissues with a high metabolic rate, such as sprouts and roots. Roots are important sinks for glyphosate, which leads to the releasing of the compound in the soil, which is later adsorbed to the soil particles and either degraded by microorganisms, or absorbed by roots of adjacent/subsequent plants (Gomes et al., 2014). However, as the cultivation took place in pots in the current study, there was a volumetric limitation for dispersion/dissipation of the glyphosate exuded by the root system, which may result in a depressive/cumulative effect to stabilize the forage root system. Vitti et al. (2019) evaluated the translocation and root exudation of glyphosate using $U$. brizantha and its transport in sugarcane and citrus and found insufficient exudates to harm the dry mass of agricultural crops. However, competitive superiority of plants occurs due to hormone effects, resulting in productive stimulus, especially initial growth speed (Barbosa et al., 2017). Plant organs with high rates of metabolism and growth are important sinks for the product (Duke, 2011). Thus, the glyphosate hormone has a significant effect on the competitive performance of plants and influences their management.

Table 4

Analysis of variance for dry root mass of Marandu grass exposed to glyphosate underdoses

$\begin{array}{cccccc}\text { Variation factor } & \begin{array}{c}\text { Degrees of } \\ \text { freedom }\end{array} & \text { Value of } F & \mathrm{CV}^{(1)}(\%) & \begin{array}{c}\text { Mean } \\ \left(\mathrm{g} \mathrm{vase}^{-1}\right)\end{array} & \begin{array}{c}\text { Number of } \\ \text { observations }\end{array} \\ \text { Doses } & 4 & 14,250^{* *} & 11,42 & 7,77 & 25\end{array}$

(1) Coefficient of variation. ** significant at $1 \%$, by Test $F$. 


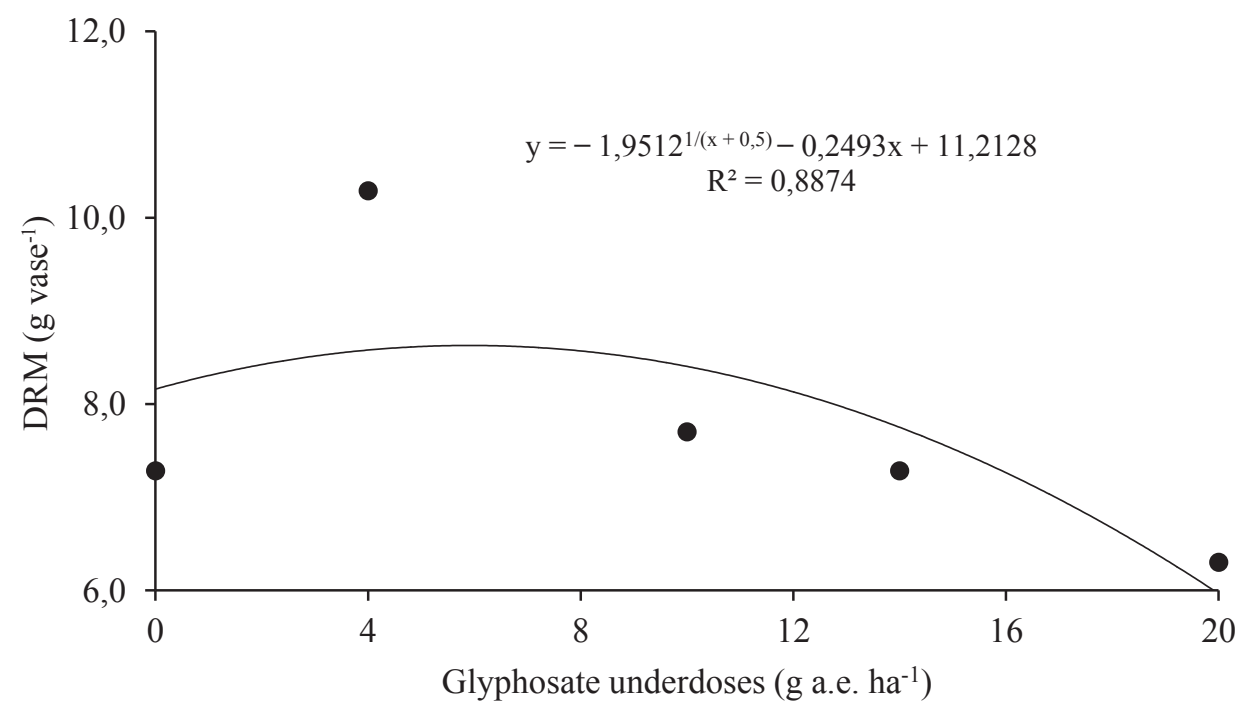

Figure 3. Production of dry root mass (DRM) of Marandu grass subjected to underdoses of glyphosate.

\section{Conclusion}

Glyphosate underdoses responded hormonally to the production and food quality of Marandu grass.

The maximum increase in DM production occurred due to the subdose of the glyphosate acid equivalent, $20 \mathrm{~g} \mathrm{ha}^{-1}$, representing $9.20 \%$ in relation to the treatment without application of the herbicide.

There was a glyphosate hormone effect for $\mathrm{CP}$, with interaction of factors (underdoses and harvest), characterized by positive linear growth in the initial cuts, and positive growth in the last two harvests, until the subdose of the glyphosate acid equivalent was $10 \mathrm{~g} \mathrm{ha}^{-1}$.

For LIG, there was a surprising linear effect, culminating in the subdose of the glyphosate acid equivalent, $20 \mathrm{~g} \mathrm{ha}^{-1}$, in relation to the treatment without application of the herbicide, with an approximate loss of $50 \%$.
Acknowledgment

We would like to thank Editage (www. editage.com) for English language editing.

\section{References}

Alencar, C. A. B., Oliveira, R. A., Cóser, A. C., Martins, C. E., Cunha, F. F., Figueiredo, J. L. A.,... Leal, B. G. (2010). Valor nutritivo de gramíneas forrageiras tropicais irrigadas em diferentes épocas do ano. Pesquisa Agropecuária Tropical, 40(1), 20-27. doi: 10.5216/pat.v40i1.3994

Barbosa, A. P., Zucareli, C., Freiria, G. H., Gomes, G. R., Bazzo, J. H. B., \& Takahashi, L. S. A. (2017). Subdoses de glyphosate no processo germinativo e desenvolvimento de plântulas de milho. Revista Brasileira de Milho e Sorgo, 16(2), 240-250. doi: 10.18512/1980-6477/rbms. v16n2p240-250 
Berchielli, T. T., Pires, A. V., \& Oliveira, S. G. (2011). Nutrição de ruminantes (2a ed.). Jaboticabal, SP: FUNEP, Fundação de Apoio a Pesquisa, Ensino e Extensão.

Brito, I. P. F. S., Tropaldi, L., Carbonari, C. A., \& Velini, E. D. (2017). Hormetic effects of glyphosate on plants. Pesticide Management Science, 74(5), 1064-1070. doi: $10.1002 / p s .4523$

Cantarutti, R. B., Alvarez, V. V. H., \& Ribeiro, A. C. (1999). Pastagens. In A. C. Ribeiro, P. T. G. Guimarães, \& V. V. H. Alvarez (Eds.), Comissão de fertilidade do solo do Estado de Minas Gerais. Recomendação para o uso de corretivos e fertilizantes em Minas Gerais (pp. 332-341). Viçosa, MG: Editora.

Carbonari, C. A., Gomes, G. L. G. C., Velini, E. D., Machado, R. F., Simoes, P. S., \& Macedo, G. C. (2014). Glyphosate effects on sugarcane metabolism and growth. American Journal of Plant Sciences, 5(24), 3585-3593. doi: 10.4236/ajps.2014.524374

Detmann, E., Souza, M. A., Valadares, S. C., Fo., Queiroz, A. C., Berchielli, T. T., Saliba, E. O. S.,... Azevedo, J. A. G. (2012). Métodos para análise de alimentos - INCT - Ciência Animal. Visconde do Rio Branco: Suprema.

Dias, M. B., Fo. (2012). Formação e manejo de pastagens. (EMBRAPA Amazônia Oriental. Comunicado Técnico, 235). Belém, PA: EMBRAPA Amazônia Oriental.

Duke, S. O. (2011). Glyphosate degradation in glyphosate - susceptible crops and weeds. Journal of Agricultural and Food Chemistry, 59(1), 5835-5841. doi: 10.1021/jf102704x

Ferreira, D. F. (2019). SISVAR: a computer analysis system to fixed effects split plot type designs. Revista Brasileira de
Biometria, 37(4), 529-535. doi: 10.28951/ rbb.v37i4.450

Fontes, J. G. G., Fagundes, J. L., Backes, A. A., Barbosa, L.T.,Cerqueira, E.S.A.,Silva,L.M.,... Vieira, J. S. (2014). Herbage accumulation in Brachiaria brizantha cultivars submitted to defoliation intensities. Semina: Ciências Agrárias, 35(3), 1425-1438. doi: 10.5433/1679-0359.2014v35n3p1425

Gitti, D. C., Arf, O., Peron, I. B. G., Portugal, J. R., Corsini, D. C. D. C., \& Rodrigues, R. A. F. (2011). Glyphosate como regulador de crescimento em arroz de terras altas. Pesquisa Agropecuária Tropical, 41(4), 500-507. doi: 10.5216/pat.v41i4.10160

Gomes, M. P., Le Manac'h, S. G., Hénault-Ethier, L., Labrecque, M., Lepage, L., Lucotte, M., \& Juneau, P. (2017). Glyphosate-dependent inhibition of photosynthesis in willow. Fronties in Plant Science, 8(207), 13. doi: 10.3389/fpls.2017.00207

Gomes, M. P., Smedbol, E., Chalifour, A., Hénault-Ethier, L., Labrecque, M., Lepage, L.,... Juneau, P. (2014). Alteration of plant physiology by glyphosate and its byproduct aminomethylphosphonic acid: an overview. Journal of Experimental Botany, 65(17), 4691-4703. doi: 10.1093/jxb/eru 269

Hanisch, A. L., Balbinot, A. A., Jr., \& Vogt, G. A. (2017). Desempenho produtivo de Urochloa brizantha cv. Marandu em função da inoculação com Azospirillum e doses de nitrogênio. Revista Agro@ mbiente On-line, 11(3), 200. doi: 10.18 227/1982-8470ragro.v11i3.3916

Kappes, C., Arf, M. V., Arf, O., Gitti, D. C., \& Ferreira, J. P. (2012). Resposta da crotalária à épocas e subdoses de aplicação de 
glifosato. Bioscience Journal, 28(3), 373383. doi: 10.5216/pat.v41i4.10160

Lopes, M. N., Cândido, M. J. D., Pompeu, R. C. F. F., Silva, R. G., \& Bezerra, F. M. L. (2011). Componentes estruturais do resíduo póscorte em capim-massai adubado com cinco doses de nitrogênio. Revista Ciência Agronômica, 42(2), 518-525. doi: 10.1590/ S1806-66902011000200035

Meschede, D. K., Velini, E. D., Carbonari, C. A., \& Moraes, C. P. (2011). Efeitos do glyphosate nos teores de lignina, celulose e fibra em Brachiaria decumbens. Revista Brasileira de Herbicidas, 10(1), 57-63. doi: 10.7824/ rbh.v10i1.77

Miranda, C. C. B., Florentino, L. A., Rezende, A. V., Nogueira, D. A., Leite, R. F., \& Naves, L. P. (2018). Desenvolvimento de Urochloa brizantha adubada com fonolito e inoculada com bactérias diazotróficas solubilizadoras de potássio. Revista de Ciências Agrárias, 41(3), 41-50. doi: 10. 19084/RCA17011

Nascentes, R. F., Carbonari, C. A., Simões, P. S., Brunelli, M. C., Velini, E. D., \& Duke, S. O. (2017). Low doses of glyphosate enhance growth, CO2 assimilation, stomatal conductance and transpiration in sugarcane and eucalyptus. Pest Management Science, 74(5), 1197-1205. doi: 10.1002/ps.4606

Oliveira, D. A., Bonfim-Silva, E. M., Silveira, C. P., \& Monteiro, F. A. (2010). Valor nutritivo do capim-braquiária no primeiro ano de recuperação com aplicações de nitrogênio e enxofre. Revista Brasileira de Zootecnia, 39(4), 716-726. doi: 10.1590/ S1516-35982010000400004

Silva, F. M., Duke, S. O., Dayan, F. E., \& Velini, E. D. (2015). Low doses of glyphosate change the responses of soyabean to subsequent glyphosate treatments. Weed Research, 56(2), 124-136. doi: 10.11 11/wre.12189

Su, Y.S., Ozturk, L., Cakmak, I., \&Budak, H. (2009). Turfgrass species response exposed to increasing rates of glyphosate application. European Journal of Agronomy, 31(3), 120-125. doi: 10.1016/j.eja.200 9.05.011

Taiz, L., \& Zeiger, E. (2013). Fisiologia vegetal (5a ed.). Porto Alegre: Artmed.

United States Department of Agriculture (2020). Livestock and poultry: world markets and trade. Retrieved from https:// apps.fas.usda.gov/psdonline/circulars/ livestock_poultry.pdf

Vitti, M. L., Alves, P. A. T., Mendes, K. F., Pimpinato, R. F., Guimarães, A. C. D., \& Tornisielo, V. L. (2019). Translocation and root exudation of glyphosate by Urochloa brizantha and its transport on sugarcane and citrus seedlings. Planta Daninha, 37, e019183334. doi: 10.1590/s0100-8358 2019370100030

Vivancos, P. D., Driscoll, S. P., Bulman, C. A., Ying, L., Emami, K., Treumann, A.,... Foyer, C. H. (2011). Perturbations of amino acid metabolism associated with glyphosatedependent inhibition of shikimic acid metabolism affect cellular redox homeostasis and alter the abundance of proteins involved in photosynthesis and photorespiration. Plant Physiology, 157(1), 256-268. doi: 10.1104/pp.111.181024

Zobiole, L. H. S., Bonini, E. I., Oliveira, R. S., Kremer, R. J., \& Ferrarese, O., Fo. (2010). Glyphosate affects lignin content and amino acid production in glyphosateresistant soybean. Acta Physiologiae Plantarum, 32(5), 831-837. doi: 10.1007/ s11738-010-0467-0 